\title{
The politics of doping and anti-doping in Chinese sport
}

To cite this article: (2012) The politics of doping and anti-doping in Chinese sport, The International Journal of the History of Sport, 29:1, 132-144, DOI: $10.1080 / 09523367.2012 .634988$

To link to this article: https://doi.org/10.1080/09523367.2012.634988

册 Published online: 15 Feb 2012.

Submit your article to this journal 2

Џ Article views: 555

Q View related articles $\square$

Citing articles: 2 View citing articles ㄴ 


\section{The politics of doping and anti-doping in Chinese sport}

Opening up to the outside world not only brought the spirit of competition to China but also the challenge of doping and anti-doping in Chinese sport. We now turn our attention to the factors that caused doping in sport in the context of politics, policy and practice in Chinese society.

\section{Doping and Chinese sport: a brief history}

Drug use in sport outside China did not affect Chinese sport until the 1980s when China opened its door and rejoined the international sports community. Doping then started to take place and continued to corrupt China's elite sport system in the 1990s. China's reputation was brought down by a series of high-profile doping scandals. Between 1988 and 1998, 52 international Chinese athletes tested positive for anabolic steroids. Some of China's most elite athletes were stripped of their medals in major international competitions for using performance-enhancing drugs.

Suspicion of drug use by Chinese athletes had reached a feverish stage in September 1994 when the Chinese women's swimming team captured 12 of 16 gold medals at the 1994 FINA World Aquatics Championships in Rome. It was believed that the Chinese swimmers were using illicit substances to enhance their performance. Coaches from 18 Western nations signed a petition demanding that the Fédération Internationale de Natation (FINA) conduct more out-of-competition drug testing. ${ }^{1}$ Therefore, on 30 September 1994, two days before the 12th Asian Games which were to be held in Hiroshima, Japan, 16 Chinese athletes were met with an unexpected request for urine samples. Together with the urine samples from 719 other athletes taken during the Asian Games, they were tested at the Mitsubishi laboratory in Tokyo, one of the International Olympic Committee (IOC) sanctioned labs. The results were announced late in November 1994 and 11 Chinese athletes, seven of them swimmers, including three female world champions, had tested positive for the use of a banned anabolic steroid, dihydrotestosterone (DHT). ${ }^{2}$

So many test positive cases from one country at one event shocked the media, the FINA and the IOC. Suspicion of a state run doping programme emerged and people began to question the credibility of Chinese sport. The issue was discussed at an IOC session in December 1994 and the 11 Chinese athletes were suspended for two years from participating in domestic and international sport events. The Chinese Olympic Committee denied the accusation of state-sponsored drug use but acknowledged that the drugs might be supplied by coaches and trainers. An internal investigation was conducted. ${ }^{3}$ In that year, the Sports Ministry reported that another 13 Chinese athletes tested positive for banned drugs. One year later, four Chinese track and field 
athletes were banned by the Sports Ministry from competing after testing positive for doping. Zhang Taibing, a men's 200m runner, and Zuo Xinxia, a women's marathon runner, were banned for four years for testing positive for steroids. The other two athletes were given three-month suspensions for 'unintentionally' taking cold medications during competition. ${ }^{4}$

Another massive doping incident happened in January 1998 before the FINA World Swimming Championships took place in Perth, Australia. A Chinese swimmer Yuan Yuan was found on arrival at Sydney airport to be carrying a flask containing 13 glass vials of muscle-building human growth hormone. She and her coach, Zhou Zhewen, were disqualified from the championships. Following this incident, four Chinese female swimmers failed pre-competition doping tests for the diuretic triamterene. ${ }^{5}$ The Chinese were humiliated by rival nations and the national swimming squad was condemned as a team of cheats and liars. ${ }^{6}$ Some coaches and the Western media claimed that the Chinese government systematically drug athletes, especially young females. ${ }^{7}$ In response to the incident, the Chinese Olympic Committee (COC) punished 24 athletes and coaches for doping or handing out banned drugs in $1998 .^{8}$

Although no 'international incident' happened to Chinese athletes in the 2000s, there were constant reports of drug use in sport in China. Less than 10 days before the 2000 Sydney Olympic Games, China dropped 14 track and field athletes, seven rowers, four swimmers and two kayakers, from its Olympic team after six runners and several rowers tested positive for the banned substance Erythropoietin (EPO). ${ }^{9}$ The action was praised by IOC executive board member He Zhengliang as a brave decision. ${ }^{10}$ The IOC "proclaimed the news as a "new beginning," proof that the war against drugs in sport, which has been waged with only limited success for three decades, was finally being won'. ${ }^{11}$

In July 2000, two female runners, Song Liqing and Yin Lili from Liaoning provincial athletic team, were banned for participation in any sport competition for two years after testing positive for testosterone. ${ }^{12}$ In 2001, four women weightlifters, one boxer, one swimmer and three field athletes tested positive for banned substances and were punished by the Sports Ministry accordingly. Most of them were fined and were banned from competition for two years. ${ }^{13}$

On 8 August 2002, when officials from the Sports Ministry made a surprise visit to the Shenyang Sports School, they found that the school's medical practitioner had been injecting banned drugs to several students. It was the first collective doping scandal in China involving school students. Further investigations were made in August and September 2002 and it was reported that 45 teenage students in the school had been systematically drugged. The media condemned the scandal as a 'crime'. ${ }^{14}$ The school principal and several staff members were removed from their posts. The school was suspended from participating in sporting events. ${ }^{15}$ Also in 2002, two Chinese swimmers, one of whom was a member of China's world record holding 4 x 100m freestyle relay team, tested positive for an anabolic steroid. In 2004, 40 athletes, coaches and officials were axed from China's Olympic team due to suspicious blood test results.

In October 2005, top Chinese distance runner and World Championship bronze medallist Sun Yingjie tested positive for androsterone after finishing second in the $10,000 \mathrm{~m}$ at the National Games. She was stripped of her silver medal and received a two-year ban. Her coach Wang Dexian received a life ban for a second violation of anti-doping rules. They were also fined 10,000 RMB each by the Chinese Athletics 
Association in January 2006, although Sun insisted that she was innocent and had been set up by her team-mate. ${ }^{16}$

In a doping raid on the Liaoning Anshan Sports School on 8 August 2006, officials from the Chinese Olympic Committee Anti-doping Commission and the Sports Ministry found 25 bottles of EPO, nine bottles of testosterone and 17 bottles of unidentified drugs in a room where school staff had been injecting drugs into students. Another 300 portions of EPO, nine bottles of testosterone and 141 bottles of steroids were found in the school principal's office. Students involved were between 15 and 18 years old. The Sports Ministry showed deep concern about the incident. Not only because it was the second collective doping scandal involving school students after the 2002 Shenyang Sports School incident, but also because it happened after the enforcement of 'China's Anti-Doping Code' that had been issued in 2004. The case sent a shock wave across the country and the principal and staff members involved were removed from post under article 42 of the Code. ${ }^{17}$ However, none of them were put behind bars due to the difficulty in pressing "criminal charges ... because of the difficulty in deciding on physical harm to the drugged athletes, while law enforcement departments cannot intervene in anti-doping investigations as there are no laws to back them up'. ${ }^{18}$ The incident brought calls for reform and in 2010, Jiang Zhixue, the head of doping control in the Sports Ministry and a member of the World Anti-Doping Agency (WADA), urged the National People's Congress to add specific terms into criminal law. ${ }^{19}$

The most recent doping sensation happened in June 2008 when China's top backstroke swimmer, Ouyang Kunpeng, and his coach Feng Shangbao received lifelong bans from the Chinese Swimming Association. The 25-year-old swimmer was a rising star who had won three individual silver medals at the 2006 Asian Games, three golds at the 2003 World University Games and it was hoped that he would contribute a gold medal for China at the 2008 Beijing Olympics. ${ }^{20}$ However, Ouyang tested positive in an out-of-competition test on 1 May 2008. An official from the Chinese Swimming Association commented on 27 June 2008: 'We are going to take a clear stand on anti-doping work and firmly crack down on any violations'. ${ }^{21}$ One month later, on 2 July 2008 Chinese wrestler Luo Meng and his coach Zhang Hua also received lifetime bans after Luo tested positive in an out-of-competition test. Between January and August 2008, 5,000 Chinese athletes were tested by the Chinese Olympic Committee Anti-doping Commission. Eight of them, including two swimmers, one wrestler, two track and field athletes, one weightlifter and two divers tested positive and were banned by the Sports Ministry. ${ }^{22}$

\section{The reasons for doping in sport in China}

\section{Gold medal fever and politics}

Duncan Mackay once said, 'We cannot rule out the possibility that some athletes use stimulants. The problem is that the media over-emphasises the importance of gold medals. Winners become heroes, so athletes and coaches create a culture of gold medal worship'. ${ }^{23}$ The gold medal worship culture which was created in China due to historical and political reasons has made drug use almost irresistible. In 1990 the government set a target of becoming a top world sports power by the end of the century. In 1993 and 2001 China bid twice to host the Olympic Games. The success of the bid to host the 2008 Olympic Games stimulated a set of new objectives in China. As Jiang Zemin, the Communist Party General Secretary between 1989 and 
2003, stated: 'The success of the bid will advance China's domestic stability and economic prosperity. The Olympics in China has the objective of raising national morale and strengthening the unity of Chinese people both in the mainland and overseas'. ${ }^{24}$ The Olympics, of course, are the best place for China to present its credentials as a superpower. This puts officials, coaches and athletes under enormous pressure and some of them hoped to achieve the goal by a shortcut of using performance-enhancing drugs.

\section{Financial and political rewards}

At the same time, money plays its part. In modern commercialised China, the reformed sports system encourages financial rewards and corporate sponsorship. Medal winners receive huge sums from the state and from sponsors. For example, while the Chinese average wage is about 1,000 RMB per month the state rewarded gold medal winners with lump sums of 8,000 RMB in 1984, 18,000 in 1988, 80,000 in 1992 and 150,000 in the 2004 Olympics. In addition, the winners received money from various sponsors and commercial channels. For example, Liu Xiang, an Olympic hurdles gold medallist, received more than 1 million RMB from various sponsors and media agencies after the Athens Games. Winner's coaches and officials also receive rewards from the state and sponsors. At the same time outstanding athletes were hailed as national heroes and icons and appointed to be representatives of the national and provincial People's Assembly, Communist Party's Congress and various social and political committees in China. Those sports officials paid particular attention to their athletes' performance at national and international competitions, for their career promotion was directly linked to them.

\section{Easy access to drugs}

Drug use is not simply a problem of sport but is also a problem of the nation. The Communist government banned drug use in China, especially opium, when the People's Republic was established in 1949. It was not until the 1980s when China opened its doors that drug use among Chinese people again became an issue. In November 1990 the State Council set up the National Anti-doping Committee. The People's Parliament issued 'The Decree of Anti-doping' in December 1990. In January 1995 the government issued 'Regulations of Anti-doping by Force'. To implement the Regulations 695 rehabilitation centres were set up by 1997 and 650,000 drug users had been sent for rehabilitation by police. From 1984 to 2004 1.14 million people from 2,000 counties and cities were registered as drug use regulars and of them $70 \%$ were youths. ${ }^{25}$

However, medicines other than strictly controlled drugs (for example, morphine, heroin and cannabis), could be bought on the open market and on the Internet. These included drugs that might enhance athletes' performance. It is an open secret that hospitals and clinics provide 'doctor's recipes' for athletes and coaches. In July 2008, just one month before the Beijing Olympics, a documentary entitled 'Flying High in Middle Kingdom' broadcasted by Germany's ARD network revealed the ongoing drug trade in China. It showed a reporter, claiming to be a swimming coach, inquiring about performance-enhancing treatment for athletes in a local hospital. Filmed covertly, a doctor quoted a price of US $\$ 24,000$ and explained the procedure as follows: 
Yes. We have no experience with athletes here, but the treatment is safe and we can help you. It strengthens lung function and stem cells go into the bloodstream and reach the organs. It takes two weeks. I recommend four intravenous injections . . 40 million stem cells or double that, the more the better. We also use human growth hormones, but you have to be careful because they are on the doping list. ${ }^{26}$

David Howman, the general director of WADA, used the words 'terrible' and 'shocking' to describe his feelings after watching the documentary. He commented that Chinese doctors 'showed such a lack of ethics and experimented with humans for a lot of money'. ${ }^{27}$

In addition, some companies, doctors and medical practitioners even come to training centres and teams to sell drugs to coaches and athletes in the open. They give the people who buy their drugs a large commission. There are stories of both the drug dealers and the people who buy the drugs becoming millionaires in a short time. A head coach of the national athletic team stated:

I am very disappointed by the current situation. Many coaches now don't pay attention to how to enhance their athletes' performance by scientific and hard training but rather by taking drugs. They spend a lot of time to learn which drug is more effective for their athletes. ${ }^{28}$

\section{Anti-doping in Chinese sport: a political issue}

From the late 1980s, Western media and some academics and observers began to question Chinese world champions' credibility and claimed that Chinese athletes were caught up in a state-run drug programme. China's credibility and reputation were under serious threat, not only in sport, but also in business and beyond. The Chinese government had to take action to clear up this mess and fix its international reputation. How China dealt with doping in sport now became an important political matter for the government.

China introduced its first anti-doping policy in August 1985 - it was entitled 'Regulation on the Research and Use of Nutritional Supplements for Athletes'. The decree declared: 'The IOC's regulations on doping must be implemented. Anti-doping tests must be conducted during national level sporting events'. ${ }^{29}$ In July 1987, China's first Anti-doping Testing Centre was established in Beijing. It was recognised by the IOC in 1989. ${ }^{30}$ In March 1989 the Sports Ministry, announced 'Three Serious Principles': to seriously forbidden drug use in sport; to seriously conduct drug tests; and to seriously punish those who use drugs in sport. It issued the 'Regulation of Anti-doping in National Sports Competitions'. On 3 May 1989, the Sports Ministry established a policy entitled 'Enforce the ban, carry out close inspection and implement serious punishment' to direct the anti-doping campaign. On 19 May 1989, a national regulation for doping testing began to take effect. ${ }^{31}$

However, the above policies and decrees failed to have the desired effect. As Yang and Leung stated, 'Embarrassing doping scandals at the 1994 Asian Games and especially at the 1998 FINA World Swimming Championships placed the Chinese sports authorities and the national leadership on the defensive and provided ammunition for China's critics'. ${ }^{32}$ Consequently, more and more strict rules and policies were set to stop drug use in sport. The shameful 1994 Asian Games gave birth to the 'Sports Law of the People's Republic of China' issued by the Sports Ministry on 1 October 1995. The decree created a legal basis for China's anti-doping campaign. 
It stated: 'Athletes, coaches, referees and organizers of sports competitions should obey sports ethics and anti-doping regulations ... Those who use drugs in sport will be punished according to law'. ${ }^{33}$ Two days after the 1998 FINA World Swimming Championships in Perth, the Sports Ministry issued the 'Urgent Notice on Ban on Drug Use in Sport' on 19 January 1998. Between 1989 and 1999 the Chinese sports authority issued 30 decrees and regulations to fight against doping in sport.

More progress was made in the 2000s. On 1 March 2004 the State Council issued the 'Code of Anti-doping in China'. It demonstrated the Chinese government's determination to fight against drug use in Chinese society in general and in sport in particular. It provided a coordinated policy and an overall framework for doping control.

In the meantime, progress was being made towards joining the international antidoping policy and organisations connected with it. China has been a World Antidoping Agency (WADA) Foundation Board member since 2000. It signed the Copenhagen Declaration and accepted the World Anti-Doping Code in 2003. The Code was translated into Chinese in February 2004 and the information was available for athletes and public review. It also cooperated with Norway in 2001 and Australia in 2002 to exchange information and establish the doping quality control system. After 10 years' effort China established its National Doping Control Quality System which received the international standard certification in 2004 and won international credibility. The latest news of the government-led anti-doping campaign came on 29 September 2010 when the Chinese Sports Ministry launched the Chinese Mandarin version of Arne Lundqvist's book Doping Nemesis. Lundqvist is Chairman of the IOC Medical Commission and WADA Vice-President and his book is now used as mandatory training material for all doping control staff members in China. ${ }^{34}$

\section{The doping control system}

The Chinese Olympic Committee Anti-doping Commission (COCADC) was established in 1990. It is directly under the leadership of the Chinese Sports Ministry and the Chinese Olympic Committee. Its major function is to implement regulations and rules of anti-doping in sport and promote drug-free sport in China. There are two divisions in the COCADC: the Testing Division and the Administration Office. The Testing Division is responsible for carrying out the national testing programme, developing the annual testing plan, conducting testing distribution and promoting training programmes for doping control officers. By 2004 there were 273 doping control officers (120 men and 153 women) in China, of which 173 were in Beijing and the rest were in the provinces. They are a major resource for the National Games and for the Olympics. The Administration Office is responsible for the administration of the COCADC; producing anti-doping education programmes; cooperating with international organisations; and acting as an inspector for the Chinese Sports Ministry for its overall anti-doping policy and practice.

COCADC is not an independent organisation. It is under the direct leadership of the Sports Ministry and of the Chinese Olympic Committee and facilitates coordination of those bodies with national sports associations from grassroots to senior management level. Every sports association is required to provide its calendar each year to COCADC. COCADC organises an annual meeting with high-risk sports associations, for example swimming and track and field, to discuss with them 
the total number of intended tests. The sports associations could suggest testing numbers, COCADC makes the decision according to the sport's profile and participation numbers.

Athletes in high-risk sports are required to report their whereabouts and contact information to their sports association when they are leaving their permanent residence or regular training camp for more than 48 hours. This does not apply to lower risk sports, such as badminton and martial arts.

The China Stimulant Test Centre was set up in 1989 and passed the IOC's annual examinations from 1989 to 2002 and has enjoyed WADA accreditation since 2003. It is responsible for analysing all doping samples collected by COCADC in China. The Director of the Centre is one of the six members of the IOC Medicine Committee's Stimulant Subcommittee. The centre participated in the joint research project to develop EPO detecting methods with Australia, France, Canada and Norway.

In short, the Chinese government and sports authorities have taken measures to combat drug taking in sport at every level and have imposed severe punishments on drug cheats - athletes, coaches, doctors and officials. ${ }^{35}$ They understand that efficient enforcement of these measures is vital if China wants to improve, not damage further, its sports and, more importantly, its political image on the international stage. $^{36}$

In 2004 at the Athens Olympics Chinese athletes were tested more than 150 times and the results were all negative, that is, they were clear. The national squad won 32 gold, 17 silver and 14 bronze medals. Their 32 gold medals put China above Russia and second to the USA. Shi Kangcheng, the Head of COCADC, proudly claimed after the Games that China had won a gold medal for doping control in sport, and that this was more important than the other gold medals China had won at the Olympics. David Howman, the WADA director general was pleased about China's commitment to anti-doping policy and practice in recent years. He commented in 2005: 'We are very pleased with the support by the Chinese government. The quantity is increasing, the quality is improving and their commitment is undoubted' ${ }^{37}$

In 2008, during the Beijing Olympic Games more than 4,700 doping tests were conducted, which was more than that of the 2000 Sydney Games, which had conducted 3,000 tests, and of the Athens Games in 2004, which had conducted 3,500 tests. $^{38}$ It was also the first time that new testing methods were introduced to detect human growth hormone. Seven athletes failed doping tests before and during the Games. ${ }^{39}$ None of the 469 Chinese athletes tested positive. ${ }^{40}$

\section{The secret life of Ma's Army}

We cannot complete the story of Chinese sport at the turn of the century without examining the secret life of the famous Ma's Army. Ma's Army refers to the athletic team coached by Ma Junren, a famous Chinese track coach, in the 1990s and early 2000s. Ma was born in 1944 to a farmer family in Liaoning province and he started his career in sport as a physical education teacher in a rural middle school in Anshan in 1971. He developed his own training methods to train distance runners and successfully brought the school's track team to top the region. He was then promoted by the local education commission and served as track coach in several secondary schools in Anshan city before he was appointed as head coach of the female distance running team of Liaoning province in $1988 .^{41}$ 
Ma Junren's effective training methodology included encouragement, nutritional tonics using traditional Chinese medicine and military-style and family-like management. He turned rural teenage girls into world class runners in the early 1990s. 'Ma's Army' became well known when three female runners coached by him won the gold medals for the women's $10,000 \mathrm{~m}, 3,000 \mathrm{~m}$ and 1,500 $\mathrm{m}$ at the 4th World Championships in Athletics in Stuttgart, Germany between 13 and 22 August 1993. One month later led by Wang Junxia, five athletes from 'Ma's Army' set new world records for the 1,500 m, 3,000 m and 10,000 m at the 7th National Games in Beijing. Time magazine stated that 'Wang Junxia sheared 41.9 seconds off the previous record in the $10,000 \mathrm{~m}$ endurance race, even though she had ranked just 56 th in the world a year earlier'. 'Ma's Army' also won the individual and team competition at the 1993 Spain World Cup Marathon in October 1993. These records 'underscored the sudden dominance of Chinese runners in women's distance events'. 43

Ma's Army's astonishing performances caught the world's attention. The star runner Wang Junxia received the 1994 Jesse Owens International Trophy Awards in New York, making her the first Asian to win the Owens award. However the meteoric rise of the Chinese runners led to suspicion that the runners used performance-enhancing drugs. The question was first raised by several Western coaches and athletes at the 4th World Championships in Athletics in Stuttgart in August 1993 when the Chinese won the 1,500, 3,000 and 10,000 metres. The questions multiplied after Wang Junxia bettered the world record for female's 3,000 $\mathrm{m}$ and 10,000 $\mathrm{m}$ at the 7th National Games in Beijing in September 1993.

Some Western athletes and coaches were convinced that Wang Junxia had used drugs to enhance her performance. Lisa Ondieki, the 1992 winner of the New York City Marathon, stated that she would not compete against Chinese runners because she believed that they used drugs. She told the media: 'It's a joke that a woman can run 29:30 for the 10,000 meters'. ${ }^{44}$

Arne Lundqvist, chairman of the International Amateur Athletic Federation's doping commission, responded: 'It's totally unfair to spread rumours of this type without any sort of evidence. It's a tragedy that any unexpected achievement is considered suspicious'. ${ }^{45}$ In order to stop the rumours, the International Association of Athletics Federations (IAAF) sent a team to Ma's Army to conduct several unannounced drug tests in late 1993. None of the runners on the IAAF's list tested positive. ${ }^{46}$ Coach $\mathrm{Ma}$ and his runners also denied the charges and attributed their success to hard training and traditional Chinese tonics of turtle's blood and caterpillar fungus. Wang Junxia stated in an interview in February 1994: 'I was very angry. The truth is I made it by myself and not with drugs. It is not necessary to do something other than run fast'. ${ }^{47}$ An official from the Sports Ministry claimed that it is prejudice and racism against the idea of losing to Asians that makes Westerners unable to accept the explanation that hard work and sophisticated training led to the Chinese runner's world records on the track. ${ }^{48}$

However, after the Spain World Cup Marathon in October 1993, Ma's Army was absent from international competition for nearly one year. According to Coach Ma, injury was preventing the runners from competing. He explained to the media in October 1994: 'The runners have been injured and have an assortment of foot injuries. Last year was a very difficult year, and we are recuperating and taking it slower this year [1994]' ${ }^{49}$ He also stated that the squad's disappearance had been due to 11 team members having appendectomies. 
It was not until October 1994 that Ma's Army returned to the world stage. The team participated in the Hiroshima Asian Games in Japan in October. Zhang Linli won the 3,000 m, Qu Yunxia won the $800 \mathrm{~m}$ in 1 minute 59.85 seconds and Wang Junxi won the $10,000 \mathrm{~m}$ in 30 minutes 50.34 seconds. The team was dogged by suspicions and rumours as none of the team members repeated their record times. Many sceptics claimed that Ma's Army used new performance-enhancing drugs in 1993 that cannot be tested or identified by the IAAF's technicians. ${ }^{50}$

Although Ma's Army astonished the world, discontent brewed among his 'female soldiers'. His military-style management outlawed long hair and boyfriends; there were disputes over prize money; they felt his training methods to be 'cruel' and 'inhuman'. Eventually, on 13 December 1994, athletes walked out of the training camp in Dalian. Led by Wang Junxia, six of his seven core athletes left, accusing Coach Ma of abuse, cruel training and stealing their winnings including bonus money, medals and Mercedes cars. ${ }^{51}$ A few days later, Wang Junxia spoke at an interview: 'We couldn't take it any longer. We had no freedom. We were on the brink of going crazy. The pressure was too intense ... ${ }^{52}$ Wang Junxia never returned to Ma's Army. After training with a new coach she made her trip to the Atlanta Olympics in 1996 and won the Olympic 5,000 m title there on 28 July.

Ma's reputation was hit hard by this incident and Ma's Army did not recover until late 1995 when Jiang Bo, a 17-year-old promising female runner, won the women's 5,000 $\mathrm{m}$ at the National Urban Games. ${ }^{53}$ It took Ma Junren another year to bring his 'soldiers' back to the spotlight. At the 8th National Games which were held in Shanghai in October 1997, Jiang Bo and Dong Yanmei renewed the world record of 5,000 m. Dong Yanmei, Lan Lixin and Yin Lili swept the gold, silver and bronze medals for the $10,000 \mathrm{~m}$. Subsequently, the 'second generation' of Ma's Army became the country's new hope. The team began to prepare for the 2000 Olympic Games and Ma Junren was later appointed the head coach of the national distance running team.

However, the introduction of drug testing for EPO by the IOC executive board in early September 2000 changed the fate of Ma's Army. ${ }^{54}$ A few days later, in response to the new drug testing, several blood tests were conducted by the Chinese Sports Ministry to monitor possible drug use among the country's Olympic team members. Six of the seven of Ma's runners, including former 5,000-metre world record holder Dong Yanmei failed the blood tests and were dropped from the Olympic team on 6 September 2000. ${ }^{55}$ In addition to the six runners from Ma's Army, another 21 athletes, including eight from track and field, seven rowers, four swimmers and two canoeists tested positive for EPO, and were removed from the Chinese Olympic team. Sports Minister Yuan Weimin, who made the decision to expel Ma Junren and his runners, stated: 'We are not against individuals. We trust science and we trust the tests. Anti-doping is a matter of principle. It is a political issue!'. ${ }^{56}$

Yuan Weimin recalled in 2009:

We immediately submitted the results of the test to the State Council since some of the athletes were due to represent China at the Sydney Games....I was under great pressure. I knew that some of Ma's runners were able to win gold medals at the Olympics. However, if they tested positive in Sydney, I would be responsible. Furthermore, it would affect Beijing's bid for the 2008 Olympics. ${ }^{57}$

With the endorsement of the State Council Yuan announced the decision in early April 2001. Several runners and two coaches were suspended from competition for 
two years and received fines of 10,000 to 20,000 RMB. Coach Ma received an official warning. ${ }^{58}$ However, Ma insisted that his athletes never took drugs. He issued a statement on 20 April 2001, explaining that it was the high altitude training that resulted in the high EPO rate in the runners' blood. He also stated that the urine and blood tests should not be used as evidence for drug use because the six runners were suffering dysentery when the tests were conducted. ${ }^{59}$

Nevertheless, Ma's drug therapy was an open secret. An anonymous track coach from the Shanghai athletic team told the media:

We knew Ma Junren's trick. Oxygen supply is the major issue in distance running. The more Oxygen an athlete could import into his/her circulation system, the better performance he/she could achieve. Ma Junren used a certain kind of drug to stimulate the production of oxygen-carrying red blood cells. In the past, no tests could detect the substance. Caterpillar fungus and turtle's blood, which claimed by Ma Junren as his secret recipes, can never enhance performance. It is a joke! ${ }^{60}$

Ma created the 'third generation' of the Army but it included boys as well as girls. It made a comeback in November 2001 at the 9th National Games in Guangzhou when Lin Na won the women's 1,500 m and women's marathon; and Gong Ke won the men's $10,000 \mathrm{~m}$ and men's marathon. ${ }^{61}$ But drug scandals continued to haunt the team when several of his top runners tested positive in 2001 and 2002. On 17 July 2001, female runner Li Ji tested positive in an out-ofcompetition test conducted by the IOC Medical Commission. She was suspended from competition for two years and received a fine of 80,000 RMB. None of Ma's runners made China's Olympic team for the 2004 Athens Games. Ma retired as a coach and deputy director of Liaoning Sports Commission in October $2004 .^{62}$

\section{Conclusion}

Doping in sports began in the 1980s to corrupt China's elite sport system. A series of drug scandals in the late 1980s and the 1990s seriously threatened China's credibility and reputation not only in sport, but also in business and beyond. Therefore, the Chinese government had to take action to clear up the mess and fix its international reputation. How to deal with doping in sport became an important political matter for the government. In general, the Chinese sports authorities made great progress in the fight against doping in sport from the late 1990s onwards.

However, pressure to use drugs does not diminish. To be the best in the sports world is still the ambition of most of the athletes, coaches, officials and the Chinese people; while at the same time, competitions are getting tougher; huge financial and political rewards are irresistible; and the development of doping markets gives coaches and athletes easy access to drugs. Therefore, some athletes, coaches and officials are still tempted to take shortcuts by using drugs. Sport in China, as in other countries, continues to face the challenge of how to win the battles over drug use in sport.

\section{Notes}

1. Jere Longman, 'OLYMPICS; Drug Sleuths' Surprise Produces a Breakthrough', The New York Times, 18 December 1994.

2. Ibid.

3. Ibid. 
4. 'Sports People: Track and Field; 4 Chinese Athletes Banned for Doping', The New York Times, 28 July 1995.

5. Houlihan, Dying to Win, 55.

6. Craig Lord, 'Expulsion Calls after Four more Chinese Test Positive', The Times, 15 January 1998.

7. Anita Lonsbrough, 'Australian Coach Wants Total Ban on China's Liars', The Daily Telegraph, 15 January 1998.

8. Nick Mulvenney and Gillian Murdoch, 'Chinese Doping Chronology', Reuters, http:// www.reuters.com/article/2008/07/29/us-olympics-doping-china-chronology-idUSL76132 9820080729 (accessed 22 May 2010).

9. Philip Hersh, 'China Ban A Nod To Future', Chicago Tribune, 7 September 2000.

10. Ibid.

11. 'Hopes Raised for War on Drugs as Ma's Army Beats Olympic Retreat Duncan Mackay', The Guardian, 7 September 2000.

12. Ping Wu, 'Anti-Doping Campaign Hits the Ma's Army', Sport Weekly, 8 April 2001.

13. Reporter, 'Drug Scandals In Sport In Recent Years', Enorth, http://sports.big5.enorth. com.cn/system/2008/06/27/003466901.shtml (accessed 22 May 2010).

14. Xiaomiao Li, 'Anshan Sports School's Drug Scandal is Crime', Shenzhen Business Daily, 27 August 2006.

15. Yihua Ma, 'Shenyang Sports School Was Punished for Doping the Young Athletes', China Sport Daily, 19 May 2003.

16. 'Sun Yingjie Claims Innocence Over Doping', AFP (Agence France-Presse), http:// www.chinadaily.com.cn/english/doc/2005-10/23/content_487062.htm (accessed 22 May 2010).

17. Nan Li, 'Punishment for the Anshan Scandal', Huashang Daily, 28 September 2006.

18. 'Chinese Expert Calls for Stricter Law for Anti-Doping', Xinhua. http://english. peopledaily.com.cn/90001/90779/90867/6927021.html (accessed 22 May 2010), 11.

19. Ibid.

20. 'Top Chinese Swimmer Cops Life Ban for Doping', ABC (American Broadcasting Corporation) News, http://www.abc.net.au/news/stories/2008/06/27/2288381.htm (accessed 22 May 2010).

21. 'Sun Yingjie Suspended Two Years, Coach in Life Ban', China Daily, 13 January 2006.

22. 'Luo Meng Was Banned from Competition', 21CN (21st Century Network), http:// 2008.21 cn.com/china/wrestling/2008/06/28/4891685.shtml (accessed 22 May 2010).

23. 'Hopes Raised for War on Drugs as Ma's Army Beats Olympic Retreat Duncan Mackay'.

24. Fan, Wu, and Xiong, 'Beijing Ambitions', 514.

25. 'Drug Users in China Have Reached 1,050,000 and 70\% Was Youth', People, http:// www.people.com.cn (accessed 22 May 2010).

26. 'German Documentary Reveals Possible Genetic Doping in China', DW-World, http:// www.dw-world.de/dw/article/0,,3505381,00.html (accessed 22 May 2010), 5.

27. Ibid., 13

28. Ping Wu, 'Current Situation of the Chinese Athletics', Sport Weekly, 22 October 2000.

29. 'China's Anti-Doping Campaign', China Certification And Accreditation Information Network (CAIT), http://www.cait.cn/jyjc_1/cjwt/201003/t20100330_52746.shtml (accessed 18 November 2010), 8.

30. 'Serve the Olympics: China Anti-doping Testing Centre'.

31. Zong, 'China's Anti-Doping Campaign'.

32. Yang and Leung, 'The Politics of Sports Anti-Doping in China: Crisis, Governance and International Compliance', 122

33. Legal Committee of The NPC Standing Committee, The Sports Law of the People's Republic of China, 2.

34. “Doping's Nemesis", Lundqvist's Book Launched in China', IAAF, http://www.iaaf. org/antidoping/news/newsid=58520.html (accessed 14 October 2010).

35. Ibid.

36. Shaozu Wu, 'We Must Ban Drug-Use in Sport in China', Sports Daily, 22 January 1998.

37. 'China Gets Tougher in Anti-Doping before Olympics', China Daily, 22 April 2005.

38. 'Three Doping Cases from Beijing Olympics Come To Light', China Daily, 22 September 2008. 
39. Ibid.

40. Ibid.

41. Ke, Ma Junren.

42. Hannah Beech, 'Ma's Army', TIME, http://www.time.com/time/world/article/ 0,8599,2053779,00.html (accessed 11 November 2010), 1 .

43. 'Sports People: Track and Field; Chinese Runner Shatters Record for 10,000 Meters', The New York Times, 9 September, 1993,

44. 'Sports People: Track and Field; Ondieki Refuses to Race the Chinese', The New York Times, 16 December 1994.

45. Ibid.

46. 'Surprise Drug Tests in China', The New York Times, 25 December 1993.

47. Ibid.

48. Philip Hersh, 'China Doubters Would Fill an Appendix', Chicago Tribune, 13 October 1994.

49. Philip Hersh, 'Ma’s Army' Looks Like a Lost Battalion', Chicago Tribune, 12 October 1994.

50. Guan, 'The Secret of Ma's Army'.

51. Ke, Ma Junren.

52. Teresa Poole, 'Record-Breaking Athletes Desert Gruelling Regime of Ma's Army', The Independent, 8 January 1995.

53. 'Results Plus', The New York Times, 26 October 1995.

54. EPO stimulates the production of oxygen-carrying red blood cells and is claimed to boost athletes' performance. The drug became increasingly popular with endurance athletes in the late 1990s.

55. 'Hopes Raised for War on Drugs as Ma's Army Beats Olympic Retreat Duncan Mackay'.

56. Yuan, Yuan Weiming and Chinese Sport, 26-7, 30.

57. 'Ma's Army Used To Take Performance Enhancing Drugs', Chutian Daily, 13 October 2009.

58. Baosheng Sun, 'Liaoning Provincial Athletic Team Was Banned from Competition for 1 Year for the Drug Scandal', Beijing Evening Echo, 8 April 2001; 'Two Athletes from the Ma Army Were Banned from Competition for Two Years', PLA Daily, 7 April 2001.

59. Peng Zhu, 'Ma Junren Announced That He Will Appeal', Beijing Youth Daily, 21 April 2001.

60. Wei Zhang, 'Yuan Weiming Uncovered the Ma Army's Drug Scandal', Xinmin Weekly, 14 October 2009.

61. Chunfei Xiao and Chusnheng Fan, 'Ma's Army Won Medals at the $9^{\text {th }}$ National Games', Xinhua, http://news.xinhuanet.com/newscenter/2001-11/19/content_122646.htm (accessed 19 November 2010).

62. Mark McDonald, 'Sprinter Is Barred in the Latest Doping Scandal for China', The New York Times, 27 October 2009.

\section{References}

'Serve the Olympics: China Anti-Doping Testing Centre'. Chinese Inspection and Quarantine, no. 11 (2007): 58.

Guan, Dong. 'The Secret of Ma's Army'. Sport Collection, no. 1 (2002): 11.

Fan, Hong, Ping Wu, and Huan Xiong. 'Beijing Ambitions: An Analysis of the Chinese Elite Sport System and Its Olympic Strategy for the 2008 Olympic Games'. The International Journal for the History of Sport, 22, no. 4 (2005): 510-529.

Ke, Yunlu. Ma Junren. Beijing: Changjiang Literature Press, 2004.

Lao, Liang. 'The Bid for the Olympics (1)'. New Sport, no. 8 (1992): 22-23.

Lasater, Martini. The Changing of the Guard, President Clinton and the Security of Taiwan. San Francisco: Westview Press, 1995.

Legal Committee of The NPC Standing Committee. The Sports Law of the People's Republic of China. Beijing: People's Sport Press, 1996.

The Beijing Organising Committee for the Games of the XXIX Olympiad. Collection of the Documents for the Bid of the 2008 Olympics. Beijing: People's Sport Press, 2002. 
Tucker, Nancy. 'The Clinton Years: The Problem of Coherence'. In Making China Policy, ed. Ramon H. Myers, Michel C. Oksenberg, and David Shambaugh, 45-76. Lanham, MD: Rowman \& Littlefield Publishers, 2001.

Wang, Ming. 'Human Rights and Sino-US Relations: Policies and Changing Realities'. The Pacific Review 10, no. 2 (1997): 237-255.

Yang, L. Dali and Alan Leung. 'The Politics of Sports Anti-Doping in China: Crisis, Governance and International Compliance'. China: An International Journal 6, no. 1 (2008): 121-148.

Yuan, Weiming. Yuan Weiming and Chinese Sport. Nanjing: Jiangsu People's Press, 2009.

Zong, Wen. 'China's Anti-Doping Campaign'. China Sports Coaches, no. 1 (2005): 51-52. 